\title{
Sociodemographic correlates of intention to quit smoking for good among U.S. adult menthol and non-menthol smokers: Evidence from the 2013-2014 National Adult Tobacco Survey
}

\author{
Sabrina L. Smiley
}

\begin{abstract}
INTRODUCTION In the U.S. significant progress has been made to reduce cigarette use, yet menthol cigarette use is a continuing public health problem, especially among young adults and Black/African Americans. Smoking cessation is warranted to reduce smoking-related diseases and premature death. Ample evidence has demonstrated that having an intention to quit smoking is strongly associated with attaining cessation. The objective of this study was to identify and compare the sociodemographic correlates of intention to quit smoking for good between menthol and non-menthol adult smokers in the U.S..

METHODS A cross-sectional secondary data analysis was conducted on the 20132014 National Adult Tobacco Survey. Multivariable logistic regression was used to analyze individual factors and their relation to intention to quit smoking for good. The total sample was nationally representative of the U.S. population and included 10121 adult smokers aged $\geqslant 18$ years.

RESULTS Among menthol smokers, non-Hispanic Blacks (adjusted odds ratio, $\mathrm{AOR}=1.31,95 \%$ confidence interval, CI: $1.03-1.67)$ were significantly $(\mathrm{p}=0.03)$ more likely to have an intention to quit smoking for good compared to nonHispanic Whites. Young adults aged $18-25$ years $(A O R=0.70,95 \%$ CI: 0.58-0.85) were significantly $(\mathrm{p}=0.01)$ less likely to have an intention to quit compared to adults aged 50 years and older, and sexual minorities (i.e. lesbian, gay, bisexual) (AOR=0.69, 95\% CI: 0.49-0.93) were significantly ( $p=0.03)$ less likely to have the intention to quit compared to heterosexuals. Among non-menthol smokers, adults aged $26-34$ years $(\mathrm{AOR}=1.46,95 \% \mathrm{CI}: 1.13-1.88)$ and $35-49$ years $(\mathrm{AOR}=1.71$, 95\% CI: $1.34-2.20)$ were significantly ( $\mathrm{p}=0.01 ; \mathrm{p}<0.001$, respectively) more likely to have an intention to quit smoking for good compared to those aged 50 years and older.

CONCLUSIONS Study findings provide insight into the association of menthol cigarette consumption with intention to quit smoking for good, notably among Black Americans, young adults and sexual minorities. Smoking cessation efforts should consider demographics and menthol smoking status.
\end{abstract}

\section{INTRODUCTION}

Menthol and non-menthol cigarette smoking is associated with smoking-related diseases (i.e. lung cancer, chronic obstructive pulmonary disease, heart disease) and premature death ${ }^{1}$. While the overall
AFFILIATION

1 Institute for Health

Promotion and Disease

Prevention Research,

Department of Preventive

Medicine, Keck School of

Medicine, University of

Southern California,

Los Angeles, CA, United States

CORRESPONDENCE TO

Sabrina Lynn Smiley. Institute for Health Promotion and

Disease Prevention Research,

Department of Preventive

Medicine, Keck School of

Medicine, University of

Southern California,

2001 North Soto Street

Los Angeles, CA, United States

KEYWORDS

young adults, race/ethnicity, intention to quit, menthol cigarettes, sexual minority, non-menthol cigarettes

Received: 12 March 2018

Revised: 23 April 2018

Accepted: 11 May 2018 
prevalence of menthol cigarette smoking has been documented among vulnerable groups, including Black/African Americans, women, young adults, and lesbian, gay, bisexual, and transgender individuals $\mathrm{s}^{4,5}$. Such disparities are due, in part, to the targeted marketing of menthol cigarettes by the tobacco industry ${ }^{6,7}$. Moreover, menthol cigarettes appeal more to novice smokers, and evidence ${ }^{8-10}$ indicates that the flavor and cooling sensations of menthol mask the harshness of inhaling cigarette smoke and help to facilitate smoking initiation and nicotine dependence.

Smoking cessation is critical to address among smokers, given the risks of smoking-related diseases and premature mortality. Previous research ${ }^{6-8}$ suggests that menthol smokers may be less likely to have an intention to quit smoking due, in part, to menthol sensory qualities. This is significant because evidence ${ }^{11,12}$ indicates that having an intention to quit smoking is strongly associated with attaining cessation. Additionally, increasing a smoker's intention to quit is a key factor in smoking cessation interventions ${ }^{13}$. Given this knowledge, and because intention to quit smoking is an essential element of behavior change models ${ }^{14,15}$, the association with menthol smoking status warrants investigation.

Thus, the objective of this study was to draw upon recent nationally representative data and identify and compare the sociodemographic correlates of intention to quit smoking for good between menthol and non-menthol adult smokers. Such knowledge of the ways in which menthol and non-menthol smokers differ with regards to sociodemographic factors underlying intention to quit for good, may help inform interventions and tobacco control policies that could improve smoking cessation outcomes.

\section{METHODS}

\section{Data source}

Data came from the 2013-2014 National Adult Tobacco Survey (NATS) public use files ${ }^{16}$. NATS is a landline and cellular telephone survey of noninstitutionalized U.S. adult civilians aged 18 years and older. The sample comprised $70 \%$ landline and $30 \%$ cellular telephone only households. A total of 75 233 interviews were completed from October 2013 to October 2014, and the overall response rate was $36.1 \%$ ( $47.6 \%$ landline, $17.1 \%$ cellular). The complete
NATS methodology is published elsewhere ${ }^{16}$. This study was exempt from Institutional Review Board approval because NATS data were de-identified and available to the public.

\section{Measures}

Two questions from NATS were used to define current cigarette use: 'Have you smoked at least 100 cigarettes in your entire life?', with dichotomized 'yes/no' response options, and 'Do you now smoke cigarettes every day, some days, or not at all?' Respondents who reported smoking at least 100 cigarettes in their lifetime and reported now smoking cigarettes 'every day' or 'some days' were classified as current smokers. Menthol cigarette use was examined using the question: 'Currently, when you smoke cigarettes, how often do you smoke menthol cigarettes?' with response options 'all of the time', 'most of the time', 'some of the time', 'rarely', and 'never'. Because cigarette use has been shown to be occasional among certain sociodemographic groups (e.g. young adults, racial/ethnic minorities) ${ }^{17-21}$, respondents who reported smoking menthol cigarettes 'all of the time', 'most of the time' or 'some of the time' were classified as menthol smokers. Respondents who reported 'rarely' or 'never' were classified as non-menthol smokers.

\section{Dependent variable}

Intention to quit smoking for good was defined based on an affirmative response to the question: 'Are you thinking about quitting cigarettes for good?', with dichotomized 'yes/no' response options.

\section{Independent variables}

Sociodemographic variables were sex (male, female), age at survey $(18-25=1,26-34=2,35-49=3,50$ and older $=4$ ), race/ethnicity (non-Hispanic White, non-Hispanic Black, Hispanic, non-Hispanic Other - Asian Americans/Hawaiian Pacific Islanders/ American Indians/Alaskans), and highest education level (some high school, high school/general education diploma, some college, associate degree, bachelor degree, graduate degree). Sexual identity was determined using the question 'Do you identify yourself as...?' with the response options 'gay' (male respondents), 'lesbian' or 'gay' (female respondents), 'straight', 'bisexual' or 'something else'. Due to 
sample size constraints, the sexual minority category created by Johnson et al. ${ }^{22}$, combining 'gay', 'lesbian', or 'gay', 'bisexual', and 'something else', which denoted a non-heterosexual identity, was used in this analysis.

\section{Statistical analysis}

The analytic sample size was 10121 . All estimates were weighted by NATS survey weights, which account for selection probabilities from the sampling design and adjust for survey non-response ${ }^{16}$. All estimates were computed in R V.3.2.0. Multivariable logistic regression models were used to identify the significant correlates of intention to quit smoking for good separately for menthol and non-menthol smokers. A p-value of less than 0.05 was considered significant.

\section{RESULTS}

Among menthol smokers, non-Hispanic Blacks $(\mathrm{AOR}=1.31,95 \% \mathrm{CI}: 1.03-1.67$, were significantly $(\mathrm{p}=0.03)$ more likely to have have an intention to quit smoking for good compared to their nonHispanic White counterparts (Table 1). Young adults aged $18-25$ years $(\mathrm{AOR}=0.70,95 \%$ CI: $0.58-0.85)$ were significantly $(\mathrm{p}=0.01)$ less likely have an

Table 1. Adjusted odds of intention to quit smoking for good among menthol and non-menthol smokers, by sociodemographics, National Adult Tobacco Survey, 2013-2014

\begin{tabular}{|c|c|c|c|c|c|c|c|c|c|}
\hline \multicolumn{5}{|c|}{ Venthol smokers ( $\mathrm{V}=\mathbf{5 3 8 0})$} & \multicolumn{5}{|c|}{ Von-menthol smokers ( $\mathrm{V}=1771)$} \\
\hline & $\begin{array}{l}\text { Quit Cigs } \\
\text { Yes }\end{array}$ & $\begin{array}{l}\text { Quit Cigs } \\
\text { No }\end{array}$ & & & & $\begin{array}{l}\text { Quit Cigs } \\
\text { Yes }\end{array}$ & $\begin{array}{l}\text { Quit Cigs } \\
\text { No }\end{array}$ & & \\
\hline & $\begin{array}{c}\text { Vean or }(\%) \\
95 \% \text { CI }\end{array}$ & $\begin{array}{c}\text { Vean or }(\%) \\
95 \% \text { CI }\end{array}$ & $\begin{array}{c}\text { AOR } \\
95 \% \text { CI }\end{array}$ & $p$ & & $\begin{array}{c}\text { Vean or }(\%) \\
95^{\circ} \% \text { CI }\end{array}$ & $\begin{array}{c}\text { Vean or }(\%) \\
95 \% \text { CI }\end{array}$ & $\begin{array}{c}\text { IOR } \\
95 \% \mathrm{CI}\end{array}$ & p \\
\hline \multicolumn{10}{|l|}{ Sex } \\
\hline $\begin{array}{l}\text { Male } \\
(\mathrm{N}=2652)\end{array}$ & $\begin{array}{c}49.5 \\
(48.0,51.1)\end{array}$ & $\begin{array}{c}51.3 \\
(48.5,54.2)\end{array}$ & Ref & Ref & $\begin{array}{l}\text { Male } \\
(\mathrm{N}=2309)\end{array}$ & $\begin{array}{c}48.5 \\
(46.8,50.2)\end{array}$ & $\begin{array}{c}51.5 \\
(48.7,54.4)\end{array}$ & Ref & Ref \\
\hline $\begin{array}{l}\text { Female } \\
(\mathrm{N}=2637)\end{array}$ & $\begin{array}{c}50.4 \\
(48.8,51.9)\end{array}$ & $\begin{array}{c}48.6 \\
(45.7,51.4)\end{array}$ & $\begin{array}{c}0.96 \\
(0.79-1.16)\end{array}$ & 0.72 & $\begin{array}{l}\text { Female } \\
(\mathrm{N}=2378)\end{array}$ & $\begin{array}{c}51.4 \\
(49.7,53.1)\end{array}$ & $\begin{array}{c}48.4 \\
(45.5,51.2)\end{array}$ & $\begin{array}{c}1.03 \\
(0.73-1.45)\end{array}$ & 0.65 \\
\hline \multicolumn{10}{|l|}{ Sexual identity } \\
\hline $\begin{array}{l}\text { Heterosexual } \\
(\mathrm{N}=5026)\end{array}$ & $\begin{array}{c}94.3 \\
(93.6,95.0)\end{array}$ & $\begin{array}{c}92.6 \\
(91.0,94.0)\end{array}$ & Ref & Ref & $\begin{array}{l}\text { Heterosexual } \\
(\mathrm{N}=4543)\end{array}$ & $\begin{array}{c}95.9 \\
(95.2,96.6)\end{array}$ & $\begin{array}{c}95.5 \\
(94.1,96.5)\end{array}$ & Ref & Ref \\
\hline $\begin{array}{l}\text { Sexual minority } \\
(\mathrm{N}=324)\end{array}$ & $\begin{array}{c}5.6 \\
(4.9,6.3)\end{array}$ & $\begin{array}{c}7.3 \\
(5.9,8.9)\end{array}$ & $\begin{array}{c}0.69 \\
(0.49-0.93)\end{array}$ & 0.03 & $\begin{array}{l}\text { Sexual minority } \\
(\mathrm{N}=198)\end{array}$ & $\begin{array}{c}4.0 \\
(3.3,4.7)\end{array}$ & $\begin{array}{c}4.4 \\
(3.4,5.8)\end{array}$ & $\begin{array}{c}0.87 \\
(0.54-1.42)\end{array}$ & 0.51 \\
\hline \multicolumn{10}{|l|}{ Age } \\
\hline $\begin{array}{l}18-25 \\
(\mathrm{~N}=839)\end{array}$ & $\begin{array}{c}14.5 \\
(13.4,15.6)\end{array}$ & $\begin{array}{c}18.8 \\
(16.7,21.2)\end{array}$ & $\begin{array}{c}0.70 \\
(0.58-0.85)\end{array}$ & 0.01 & $\begin{array}{l}18-25 \\
(N=324)\end{array}$ & $\begin{array}{c}6.9 \\
(6.1,7.8)\end{array}$ & $\begin{array}{c}6.0 \\
(4.8,7.6)\end{array}$ & $\begin{array}{c}1.24 \\
(0.96-1.60)\end{array}$ & 0.29 \\
\hline $\begin{array}{l}26-34 \\
(N=1005)\end{array}$ & $\begin{array}{c}19.3 \\
(18.1,20.6)\end{array}$ & $\begin{array}{c}16.7 \\
(14.7,18.9)\end{array}$ & $\begin{array}{c}1.11 \\
(0.87-1.43)\end{array}$ & 0.36 & $\begin{array}{l}26-34 \\
(N=503)\end{array}$ & $\begin{array}{c}11.4 \\
(10.3,12.5)\end{array}$ & $\begin{array}{c}8.8 \\
(7.3,10.6)\end{array}$ & $\begin{array}{c}1.46 \\
(1.13-1.88)\end{array}$ & 0.01 \\
\hline $\begin{array}{l}35-49 \\
(N=1174)\end{array}$ & $\begin{array}{c}22.4 \\
(21.1,23.7)\end{array}$ & $\begin{array}{c}20.4 \\
(18.2,22.8)\end{array}$ & $\begin{array}{c}1.06 \\
(0.82-1.37)\end{array}$ & 0.57 & $\begin{array}{l}35-49 \\
(N=1072)\end{array}$ & $\begin{array}{c}24.2 \\
(22.7,25.7)\end{array}$ & $\begin{array}{c}19.1 \\
(16.9,21.4)\end{array}$ & $\begin{array}{c}1.71 \\
(1.34-2.20)\end{array}$ & $<0.001$ \\
\hline $\begin{array}{l}\geq 50 \\
(N=2332)\end{array}$ & $\begin{array}{c}43.6 \\
(42.0,45.2)\end{array}$ & $\begin{array}{c}43.9 \\
(41.1,46.7)\end{array}$ & Ref & Ref & $\begin{array}{l}\geq 50 \\
(N=2842)\end{array}$ & $\begin{array}{c}57.4 \\
(55.7,59.1)\end{array}$ & $\begin{array}{c}65.9 \\
(63.1,68.5)\end{array}$ & Ref & Ref \\
\hline \multicolumn{10}{|l|}{ Race/ethnicity } \\
\hline $\begin{array}{l}\text { NH White } \\
(\mathrm{N}=3178)\end{array}$ & $\begin{array}{c}58.8 \\
(57.2,60.4)\end{array}$ & $\begin{array}{c}69.3 \\
(66.5,71.9)\end{array}$ & Ref & Ref & $\begin{array}{l}\text { NH White } \\
(\mathrm{N}=3871)\end{array}$ & $\begin{array}{c}82.6 \\
(81.2,83.8)\end{array}$ & $\begin{array}{c}85.3 \\
(83.1,87.2)\end{array}$ & Ref & Ref \\
\hline $\begin{array}{l}\text { NH Black } \\
(\mathrm{N}=1012)\end{array}$ & $\begin{array}{c}21.9 \\
(20.6,23.2)\end{array}$ & $\begin{array}{c}12.4 \\
(10.6,14.5)\end{array}$ & $\begin{array}{c}1.31 \\
(1.03-1.67)\end{array}$ & 0.03 & $\begin{array}{l}\text { NH Black } \\
(\mathrm{N}=161)\end{array}$ & $\begin{array}{c}3.9 \\
(3.3,4.6)\end{array}$ & $\begin{array}{c}2.0 \\
(1.3,3.1)\end{array}$ & $\begin{array}{c}1.41 \\
(1.12-1.54)\end{array}$ & 0.23 \\
\hline $\begin{array}{l}\text { Hispanic } \\
(\mathrm{N}=522)\end{array}$ & $\begin{array}{c}10.1 \\
(9.2,11.1)\end{array}$ & $\begin{array}{c}8.9 \\
(7.4,10.7)\end{array}$ & $\begin{array}{c}1.23 \\
(0.98-1.55)\end{array}$ & 0.26 & $\begin{array}{l}\text { Hispanic } \\
(\mathrm{N}=278 ; 0.05)\end{array}$ & $\begin{array}{c}5.9 \\
(5.2,6.8)\end{array}$ & $\begin{array}{c}5.4 \\
(4.2,6.9)\end{array}$ & $\begin{array}{c}0.69 \\
(0.44-1.07)\end{array}$ & 0.10 \\
\hline $\begin{array}{l}\text { NH Other } \\
(\mathrm{N}=503 ; 0.09)\end{array}$ & $\begin{array}{c}9.5 \\
(8.6,10.5)\end{array}$ & $\begin{array}{c}9.7 \\
(8.1,11.6)\end{array}$ & $\begin{array}{c}1.05 \\
(0.81-1.36)\end{array}$ & .73 & $\begin{array}{l}\text { NH Other } \\
(\mathrm{N}=344)\end{array}$ & $\begin{array}{c}7.4 \\
(6.6,8.4)\end{array}$ & $\begin{array}{c}7.0 \\
(5.7,8.7)\end{array}$ & $\begin{array}{c}0.90 \\
(0.57-1.37)\end{array}$ & 0.53 \\
\hline
\end{tabular}


Table 1. Continued

\begin{tabular}{|c|c|c|c|c|c|c|c|c|c|}
\hline \multicolumn{5}{|c|}{ Venthol smokers ( $\mathrm{V}=\mathbf{5 3 8 0})$} & \multicolumn{5}{|c|}{ Von-menthol smokers ( $\mathrm{V}=$ (771) } \\
\hline & $\begin{array}{l}\text { Quit Cigs } \\
\text { Yes }\end{array}$ & $\begin{array}{c}\text { Quit Cigs } \\
\text { No }\end{array}$ & & & & $\begin{array}{l}\text { Quit Cigs } \\
\text { Yes }\end{array}$ & $\begin{array}{l}\text { Quit Cigs } \\
\text { No }\end{array}$ & & \\
\hline & $\begin{array}{c}\text { Vean or }(\%) \\
95 \% \mathrm{CI}\end{array}$ & $\begin{array}{c}\text { Vean or }(\%) \\
95 \% \text { CI }\end{array}$ & $\begin{array}{c}\text { AOR } \\
95 \% \mathrm{CI}\end{array}$ & p & & $\begin{array}{c}\text { Vean or }(\%) \\
95 \% \mathrm{CI}\end{array}$ & $\begin{array}{c}\text { Vean or }(\%) \\
95 \% \text { CI }\end{array}$ & $\begin{array}{l}\text { AOR } \\
95 \% \mathrm{CI}\end{array}$ & p \\
\hline \multicolumn{10}{|l|}{ Education } \\
\hline $\begin{array}{l}\text { Some high school } \\
(\mathrm{N}=788)\end{array}$ & $\begin{array}{c}14.6 \\
(13.5,15.7)\end{array}$ & $\begin{array}{c}15.2 \\
(13.3,17.4)\end{array}$ & Ref & Ref & $\begin{array}{l}\text { Some high school } \\
(\mathrm{N}=606)\end{array}$ & $\begin{array}{c}11.9 \\
(10.8,13.0)\end{array}$ & $\begin{array}{c}14.8 \\
(12.9,17.0)\end{array}$ & Ref & Ref \\
\hline $\begin{array}{l}\text { High school/GED } \\
(\mathrm{N}=1799)\end{array}$ & $\begin{array}{c}32.8 \\
(31.3,34.3)\end{array}$ & $\begin{array}{c}35.2 \\
(32.6,38.0)\end{array}$ & $\begin{array}{c}0.98 \\
(0.84-1.44)\end{array}$ & 0.93 & $\begin{array}{l}\text { High school/GED } \\
(\mathrm{N}=1521)\end{array}$ & $\begin{array}{c}31.6 \\
(30.0,33.2)\end{array}$ & $\begin{array}{c}33.6 \\
(31.0,36.3)\end{array}$ & $\begin{array}{c}1.20 \\
(0.96-1.58)\end{array}$ & 0.14 \\
\hline $\begin{array}{l}\text { Some college } \\
(N=1012)\end{array}$ & $\begin{array}{c}19.7 \\
(18.5,21.0)\end{array}$ & $\begin{array}{c}16.4 \\
(14.4,18.6)\end{array}$ & $\begin{array}{c}1.28 \\
(1.02-1.62)\end{array}$ & 0.10 & $\begin{array}{l}\text { Some college } \\
(\mathrm{N}=825)\end{array}$ & $\begin{array}{c}17.6 \\
(16.4,19.0)\end{array}$ & $\begin{array}{c}16.3 \\
(14.3,18.5)\end{array}$ & $\begin{array}{c}1.31 \\
(1.07-1.69)\end{array}$ & 0.06 \\
\hline $\begin{array}{l}\text { Associate degree } \\
(\mathrm{N}=870)\end{array}$ & $\begin{array}{c}16.7 \\
(15.5,17.9)\end{array}$ & $\begin{array}{c}15.1 \\
(13.2,17.3)\end{array}$ & $\begin{array}{c}1.03 \\
(0.86-1.23)\end{array}$ & 0.83 & $\begin{array}{l}\text { Associate degree } \\
(\mathrm{N}=785)\end{array}$ & $\begin{array}{c}17.0 \\
(15.8,18.3)\end{array}$ & $\begin{array}{c}14.9 \\
(13.0,17.1)\end{array}$ & $\begin{array}{c}1.36 \\
(1.06-1.75)\end{array}$ & 0.03 \\
\hline $\begin{array}{l}\text { Bachelor degree } \\
(\mathrm{N}=559)\end{array}$ & $\begin{array}{c}10.3 \\
(9.4,11.3)\end{array}$ & $\begin{array}{c}11.1 \\
(9.5,13.1)\end{array}$ & $\begin{array}{c}1.21 \\
(0.96-1.53)\end{array}$ & 0.29 & $\begin{array}{l}\text { Bachelor degree } \\
(\mathrm{N}=618)\end{array}$ & $\begin{array}{c}13.3 \\
(12.2,14.6)\end{array}$ & $\begin{array}{c}12.5 \\
(10.7,14.5)\end{array}$ & $\begin{array}{c}1.46 \\
(1.24-1.84)\end{array}$ & 0.02 \\
\hline $\begin{array}{l}\text { Graduate degree } \\
(\mathrm{N}=240)\end{array}$ & $\begin{array}{c}4.3 \\
(3.7,4.9)\end{array}$ & $\begin{array}{c}4.9 \\
(3.8,6.3)\end{array}$ & $\begin{array}{c}0.83 \\
(0.64-1.06)\end{array}$ & 0.46 & $\begin{array}{l}\text { Graduate degree } \\
(\mathrm{N}=317)\end{array}$ & $\begin{array}{c}6.9 \\
(6.1,7.9)\end{array}$ & $\begin{array}{c}6.0 \\
(4.7,7.5)\end{array}$ & $\begin{array}{c}1.39 \\
(1.15-1.77)\end{array}$ & 0.12 \\
\hline
\end{tabular}

AOR: adjusted odds ratio, $\mathrm{Cl}$ : confidence interval, $\mathrm{NH}$ : non-Hispanic, cigs: cigarettes. Ref: reference. AORs control for the covariates shown. Bold values indicate a significant difference at $p<0.05$

intention to quit smoking for good compared to their counterparts aged 50 years and older. Additionally, sexual minorities (AOR $=0.69,95 \%$ CI: 0.49-0.93) were significantly $(\mathrm{p}=0.03)$ less likely to have an intention to quit smoking for good compared to their heterosexual counterparts.

Non-menthol smokers aged 26-34 years $(\mathrm{AOR}=1.46,95 \% \mathrm{CI}: 1.13-1.88)$ and $35-49$ years $(\mathrm{AOR}=1.71,95 \%$ CI: $1.34-2.20)$ were significantly ( $p=0.01 ; p<0.001$, respectively) more likely to have an intention to quit smoking for good compared to those aged 50 years and older. Non-menthol smokers with an associate degree (AOR $=1.36,95 \% \mathrm{CI}: 1.06-$ $1.75)$ and a Bachelor's degree $(\mathrm{AOR}=1.46,95 \%$ CI: $1.24-1.84)$ were significantly $(p=0.03 ; p=0.02$, respectively) more likely to have the intention to quit smoking for good compared to those with some high school education.

\section{DISCUSSION}

This study is among the first to document an association between sexual identity and intention to quit smoking menthol cigarettes. Findings revealed that among menthol smokers, identifying with a sexual minority was associated with low intention to quit smoking for good compared to identifying as heterosexual. Black menthol smokers were more likely to have an intention to quit smoking for good than their White counterparts, and young adult menthol smokers aged 18-25 were less likely to have an intention to quit compared to their older counterparts. Among non-menthol smokers, being aged 26-34 years, 35-49 years, and having an associate's or bachelor's degree was associated with high intention to quit smoking for good, compared to their counterparts aged 50 years and older, and those with less education. These findings highlight the need for increased effort to stimulate interest in quitting, including among sexual minority and young adult menthol smokers.

Previous research ${ }^{11,12}$ has associated long-term smoking cessation with intention to quit. Although higher odds of intention to quit for good among Black menthol smokers complements existing research ${ }^{23}$, previous studies ${ }^{24,25}$ have found that Black smokers are less successful in quitting compared to White smokers. The reason for lower smoking cessation outcomes among Blacks is relatively understudied but this could be due to raciallytargeted tobacco industry marketing ${ }^{6,7}$, greater nicotine dependence ${ }^{26,27}$ and stress ${ }^{28}$. Additional factors that have been suggested are perceived lack of social support ${ }^{29}$, access and availability of evidencebased cessation resources ${ }^{30}$, and advice to quit 
smoking from primary care providers ${ }^{31}$. Given that most Black smokers prefer menthol cigarettes ${ }^{3,32,33}$, culturally-specific smoking cessation interventions targeting Black menthol smokers may help reduce this disparity.

For more than a decade, the tobacco industry has increasingly targeted young adults aged 18-25 years $^{34,35}$. The 2009 Family Smoking Prevention and Tobacco Control Act (FSPTCA) gave the Food and Drug Administration (FDA) authority to regulate tobacco products in the U.S. ${ }^{36}$. The FSPTCA banned the manufacture, import, and sales of characterizing flavors in cigarettes, except for menthol. Despite the FDA Tobacco Products Scientific Advisory (TPSAC) Board's comprehensive review of the scientific literature and recommendation ${ }^{8}$ that menthol be removed from the market, to date no regulatory actions have been taken. This study demonstrates the need to further examine quit intention among young adult menthol smokers. Young adult smokers are at increased risk for smoking-related diseases and premature mortality; quitting smoking before age 40 years can reduce smoking-related premature mortality by about $90 \%{ }^{37}$. In this study, non-menthol smokers aged 26-34 years and those aged 35-49 years were more likely to have an intention to quit for good compared to their older counterparts. Thus, interventions for educating young adult smokers about the increased risks of developing smokingrelated diseases might be a useful strategy to increase their intention to quit smoking for good. Further, policy-level interventions regulating menthol cigarettes could also improve smoking cessation outcomes.

There remains a dearth of empirical evidence $\mathrm{e}^{5,17}$ documenting the role of sexual identity in cigarette smoking and cessation in a nationally representative sample of adult smokers. Adding to the literature, this study found that menthol smokers who identified themselves with a sexual minority were less likely to have an intention to quit smoking for good compared to their heterosexual counterparts. Such results have implications for the development of prevention and cessation programs and highlight the need to understand the factors influencing these disparities. Moreover, the relationship between menthol smoking and smoking cessation among sexual minority subgroups (i.e. lesbian, gay, bisexual) merits examination in longitudinal, population-based samples.

This study has limitations. NATS data are crosssectional, and causality and temporal sequences cannot be defined. Therefore, factors beyond those examined in this study need further exploration. NATS data are subject to self-report response biase (e.g. recall, social desirability). To advance research in this area, future studies would benefit from a focus on quit attempts or smoking cessation among menthol and non-menthol smokers, with a distinction between daily and non-daily smokers. Notwithstanding, strengths of the NATS include reliability and weighted data, which make it possible to examine the generalizability of the study findings to U.S. adult cigarette smokers.

\section{CONCLUSIONS}

This study provides estimates of intention to quit smoking cigarettes for good among menthol and non-menthol smokers. Study findings inform a more recent description in the U.S. population and suggest that young adult menthol smokers aged 18-25 years have less intention to quit for good compared to their older counterparts. Additionally, findings indicate that sexual minority menthol smokers have less intention to quit smoking for good than their heterosexual peers. Identifying pathways and mechanisms underlying these disparities associated with menthol status, age and sexual identity, and developing intervention practices and policies to eliminate them, may help reduce inequalities in quitting smoking. Future research should focus on determining whether intention to quit smoking for good is associated with quit attempts and smoking cessation among menthol and non-menthol smokers of various levels (i.e. daily, non-daily) across sociodemographic groups.

\section{REFERENCES}

1. Centers for Disease Control and Prevention. Cigarette smoking among adults-United States, 2007. MMWR. 2008;57:1221-1226.

2. Giovino GA. Patterns of and Recent Trends in the Use of Mentholated Cigarettes in the United States. Silver Spring, MD:U.S. Food and Drug Administration Tobacco Product Scientific Advisory Board;2010.

3. Giovino GA, Villanti AC, Mowery PD et al. Differential trends in cigarette smoking in the USA: is menthol 
slowing progress? Tob Control. 2015;24(1):28-37. doi: 10.1136/tobaccocontrol-2013-051159

4. Substance Abuse and Mental Health Services Administration (SAMHSA). The NSDUH Report: recent Trends in Menthol Cigarette Use. 2011. Center for Behavioral Health Statistics and Quality, Rockville. MD.

5. Fallin A, Goodin AJ, King BA. Menthol Cigarette Smoking among Lesbian, Gay, Bisexual, and Transgender Adults. Am J Prev Med. 2015;48(1):93-97. doi:10.1016/j.amepre.2014.07.044

6. Anderson SJ. Marketing of menthol cigarettes and consumer perceptions: a review of tobacco industry documents. Tob Control. 2011;20(Suppl2):ii49-ii56. doi:10.1136/tc.2010.041939

7. Anderson SJ. Menthol cigarettes and smoking cessation behavior: a review of tobacco industry documents. Tob Control. 2011;20(Suppl 2):ii49-ii56. doi: 10.1136/tc.2010.041947

8. Tobacco Products Scientific Advisory Committee. Menthol cigarettes and public health: review of the scientific evidence and recommendations. Rockville (MD): Center for Tobacco Products, Food and Drug Administration, 2011.

9. U.S. Food and Drug Administration. Preliminary scientific evaluation of the possible public health effects of menthol versus non-menthol cigarettes. Silver Spring (MD): Center for Tobacco Products, Food and Drug Administration, 2013.

10. U.S. Food and Drug Administration. Reference addendum: preliminary scientific evaluation of the possible public health effects of menthol versus nonmenthol cigarettes. Silver Spring (MD): Center for Tobacco Products, Food and Drug Administration, 2013.

11. Hyland A, Borland R, Li Q, et al. Individual-level predictors of cessation behaviours among participants in the International Tobacco Control (ITC) Four Country Survey. Tob Control. 2006;15(Suppl 3):iii83-94. doi:10.1136/tc.2005.013516

12. Hyland A, Li Q, Bauer JE, et al. Predictors of cessation in a cohort of current and former smokers followed over 13 years. Nicotine Tob Res. 2004;6(Suppl 3):S363-369. doi:10.1080/14622200412331320761

13. Fiore MC, Jaen CR, Baker TB, Bailey WC, Benowitz NL, Curry SJ, Wewers ME. Treating tobacco use and dependence:2008 Update. Rockville MD:U.S. Public Health Service; 2008.

14. Prochaska J and Diclemente C. Stages and processes of self-change of smoking: toward an integrative model of change. J Consult Clin Psychol. 1983;51:390-395. doi:10.1037//0022-006x.51.3.390

15. Diclemente C, Prochaska J, Fairhurst S, Velicer W, Velasquez M, Rossi J. The process of smoking cessation: an analysis of precontemplation, contemplation, and preparation stages of change. J Consult Clin Psychol. 1991;59:295-304. doi: 10.1037/0022-006x.59.2.295
16. Centers for Disease Control and Prevention. 2013-2014 National Adult Tobacco Survey (NATS) sample design and methodology report, January 2016. http://www.cdc. gov/tobacco/data_statistics/surveys/nats/pdfs/2014methodology-report-tag508.pdf. Accessed March, 2018.

17. Husten C, McCarty M, Giovino G, Chrismon JH, Zhu B. Intermittent smokers: a descriptive analysis of persons who have never smoked daily. Am J Public Health. 1998;88:86-89. doi:10.2105/ajph.88.1.86

18. Wortley PM, Husten GG, Trosclair A, Chrismon J, Pederson LL. Nondaily smokers: a descriptive analysis. Nicotine Tob Res. 2003;5(5):755-759. doi:10.1080/1462220031000158753

19. Hammond D. Smoking behaviour among young adults: beyond youth prevention. Tob Control. 2005;14:181185. doi:10.1136/tc.2004.009621

20. Hyland A, Rezaishiraz H, Bauer J, Giovino GA, Gummings KM. Characteristics of low-level smokers. Nicotine Tob Res. 2005;7:461-468. doi:10.1080/14622200500125369

21. Wang Y, Sung HY, Yao T, Lightwood J, Max W. Factors associated with short-term transitions of non-daily smokers: socio-demographic characteristics and other tobacco product use. Addiction. 2017;112(5):864-872. doi:10.1111/add.13700

22. Johnson SE, Holder-Hayes E, Tessman GK, King BA, Alexander T, Zhao X. Tobacco Product Use Among Sexual Minority Adults: Findings from the 2012-2013 National Adult Tobacco Survey. Am J Prev Med. 2016;50(4):e91-e100. doi:10.1016/j.amepre.2015.07.041

23. Royce JM, Hymowitz N, Corbett K, Hartwell TD, Orlandi MA. Smoking cessation factors among African Americans and whites. COMMIT Research Group. Am J Public Health. 1993 Feb;83(2):220-226. doi: 10.2105/ajph.83.2.220

24. Centers for Disease Control and Prevention (CDC). Quitting smoking among adults-United States, 20052014. MMWR. 2011;60(44):1513-1519.

25. Trinidad DR, Perez-Stable EJ, White MM, Emery SL, Messer K. A Nationwide Analysis of US Racial/Ethnic Disparities in Smoking Behaviors, Smoking Cessation, and Cessation-Related Factors. Am J Public Health. 2011;101(4):699-706. doi:10.2105/ajph.2010.191668

26. Okuyemi KS, Faseru B, Sanderson Cox L, Bronars CA, Ahluwalia JS. Relationship between menthol cigarettes and smoking cessation among African American light smokers. Addiction. 2007;102:1979-1986. doi:10.1111/j.1360-0443.2007.02010.x

27. Luo Z, Alvarado GF, Hatsukami DK, Johnson EO, Bierut LJ, Breslau N. Race differences in nicotine dependence in the Collaborative Genetic Study of Nicotine Dependence (COGEND). Nicotine Tob Res. 2008;10:1223-1230. doi:10.1080/14622200802163266 28. Slopen N, Dutra LM, Williams DR et al.Psychosocial 
Stressors and Cigarette Smoking Among African American Adults in Midlife. Nicotine Tob Res. 2012;14(10):1161-1169. doi: 10.1093/ntr/nts011

29. Romano PS, Bloom J, Syme SL. Smoking, social support, and hassles in an urban African-American community. Am J Public Health. 1991;81(11):1415-1422. doi:10.2105/ajph.81.11.1415

30. Matthews AK, Sanchez-Johnsen L, King A. Development of a Culturally Targeted Smoking Cessation Intervention for African American Smokers. J Community Health. 2009;34(6):480-492. doi:10.1007/s10900-009-9181-5

31. Houston TK, Scarinci IC, Person SD, Greene PG. Patient smoking cessation advice by health care providers: The role of ethnicity, socioeconomic status, and health. 95(6):1056-1061. doi:10.2105/ajph.2004.039909

32. Heck JD. Smokers of Menthol and Non-menthol Cigarettes Exhibit Similar Levels of Biomarkers of Smoke Exposure. Cancer Epidemiol Biomarkers Prev. 2009. 18(2):622-629. doi:10.1158/1055-9965.epi-08-0550

33. Okuyemi KS, Ebersole-Robinson M, Nazir N, Ahluwalia JS. African-American Menthol and Non-menthol Smokers: Differences in Smoking and Cessation Experiences. J Natl Med Assoc. 2004. 96(9):1208-1211.

34. Lewis MJ, Wackowski O. Dealing with an innovative industry: a look at flavored cigarettes promoted by mainstream brands. Am J Public Health. 2006. 96(2):244-251. doi:10.2105/ajph.2004.061200

35. Ling PM and Glantz SA. Why and How the Tobacco Industry Sells Cigarettes to Young Adults: Evidence from Industry Documents. Am J Public Health. 2002. 92(6):908-916.

36. Family Smoking Prevention and Tobacco Control Act, Pub. L. No. 111-31. 2009.

37. Jha P, Ramasundarahettige C, Landsman V, Rostrom B, Thun M, Anderson RN, McAfee T, Peto R. 21st Century Hazards of Smoking and Benefits of Cessation in the United States. N Engl J Med. 2013;368(4):341-350. doi:10.1056/nejmsa1211128

CONFLICTS OF INTEREST The author has completed and submitted the ICMJE Form for Disclosure of Potential Conflicts of Interest and none was reported.

FUNDING

This research was supported by Truth Initiative, a non-profit tobacco control organization.

PROVENANCE AND PEER REVIEW

Not commissioned; externally peer reviewed. 